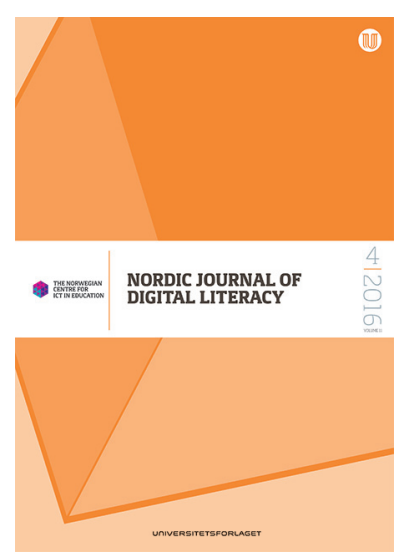

Nordic Journal of Digital Literacy, volume 11, no 4-2016 p. 207-226 ISSN online: 1891-943X

DOI: 10.18261/issn.1891-943x2016-04-01

$\overline{\text { PEER REVIEWED ARTICLE }}$

\title{
Fun and games
}

- Finnish children's ideas for the use of digital media in preschool

\section{Pekka Mertala}

Project researcher, University of Oulu, Faculty of Education

pekka-oskari.mertala@oulu.fi

\section{ABSTRACT}

This study has used drawings from and interviews with 5-6 year-old Finnish children ( $\mathrm{N}=103)$ to explore their ideas for the use of digital media in preschool. The main findings, based on data driven analysis, were the following: Playing commercial digital games was the most popular activity followed by media production, mainly photographing. Computers, tablets and cameras were the most popular devices. Digital media was understood to be more about leisure than learning. Pedagogical implementations are discussed.

\section{Keywords}

Digital media, preschool, early childhood education, digital games

\section{INTRODUCTION}

While the integration of digital media ${ }^{1}$ in early childhood education ${ }^{2}$ (ECE) has been a growing subject of academic discussion over the previous decades ${ }^{3}$, children's own ideas and perceptions are seldom the topic of scientific interest. The majority of studies rely on information provided by teachers (e.g. Blackwell, Lauricella \& Wartella, 2016; Kerckaert, Vanderlinde \& van Braak, 2015), and the ones that have paid firsthand attention to children have often focused on children's reports of what they do with digital media (e.g. Aubrey \& Dahl, 2014; McKenney \& Voogt, 2010). Studies where children evaluate the existing practices or express their ideas about the use of digital media in educational settings are rare and often concentrate on older children (Selwyn, Boraschi \& Özkula, 2009a; Selwyn, Potter \& Cranmer, 2009b; cf. Howard, Miles \& ReesDavies, 2012; Morgan, 2010).

1. This paper adapts Plowman's (2016) definition, where the term digital media refers to digital devices (i.e. computers, tablets, gaming consoles, smartphones, e-readers and televisions) and to products or outputs (i.e. applications, games, websites, movies and programs) that are viewed, played or created on these devices.

2. This paper follows the Finnish discourse, where the term 'early childhood education' is used as an umbrella category for all the institutional education that happens prior to primary school, while 'preschool' is used when addressing the final year before children start primary school.

(III)

UNIVERSITETSFORLAGET
3. The annual average for peer reviewed articles containing keywords: preschool / early childhood and digital media in the Pro Quest-database was 2.8 in the 1990 's, 12.0 in the 2000 's and 27.7 in the 2010's. 26.05.2016. 
The shortage of child-centered research is contradictory to the contemporary view of childhood, where children are understood as knowledgeable and competent agents, whose views and ideas need to be taken into consideration in the planning of polices and services (e.g. Alasuutari, Karila, Alila \& Eskelinen, 2014; Corsaro, 2005). A review of the research literature also suggests that children's and teachers' perceptions of how digital media could be used aren't necessarily congruent. Morgan (2010) asked 3-7 year-old children to evaluate whether their classroom activities with interactive whiteboards were playful or not, and unlike their teachers, the children valued the activities as not being playful. On the other hand, in the study by Howard et al. (2012), the use of computers was ranked high on their playfulness by 3-7 year-old children. As the practices, devices, the number of children and the children's ages varied between and within the aforementioned studies, no single factor influencing the experienced playfulness can be pointed at.

In the context of present-day western societies, young children's interactions with digital media mainly happen in their homes (Chaudron, 2015). Thus, the social and cultural importance of these experiences needs to be taken into concern in pedagogical planning (Buckingham, 2015). This notion is supported by Selwyn et al. (2009a), as they found that 7-11 year-old children in their drawings of "future classroom technology" imported home media devices and practices into school, and emphasized play, fun and portability. With children who experience the use of digital media in school (or in ECE), this can also be understood as a critique towards the type of media devices in the schools and what is done with them (see Selwyn et al., 2009b). Children can also be critical against the digital gap between their homes and ECE environments: digital media (for children to use) is rarely found from Finnish early years' classrooms, and children have questioned why the digital affordances between their two main educational contexts differ from each other so remarkably (Alasuutari et al., 2014).

In this study, drawings from and interviews with 5 to 6-year-old Finnish children $(\mathrm{N}=103)$ were used to explore what they would like to do with digital media in preschool. The term "idea" refers to "what if" questions and the children's thoughts about the future use of digital media. The second research interest was to examine how different contextual and cultural aspects (including - but not restricted to - the children's experiences with digital media at home) were reflected in the children's ideas.

\section{DIGITAL MEDIA IN THE PEDAGOGY OF EARLY CHILDHOOD EDUCATION}

The playing of educational games for practicing literacy and mathematics appears to be the most common ways to use digital media in ECE (e.g. Blackwell et al., 2016; McKenney \& Voogt, 2010). Buckingham (2015) however argues that (any) media cannot be regarded as a neutral means for delivering 
information, and thus teaching children about games as a cultural form is a necessary prerequisite for using games in order to teach other curriculum areas. Also, in the Finnish Core Curriculum for Preschool Education (later: core curriculum), digital media is understood to be both a tool for and a subject of learning. For example, while games - both traditional and digital - are regarded as a useful medium for learning, the core curriculum also calls children to have opportunities to explore digital games. (Finnish National Board of Education [FNBoE], 2014.) According to Buckingham and Burn (2007), the learning of games can be understood as a development of functional and critical game literacy. Functional literacy includes basic hardware skills (i.e. the ability to load and save a game) and software skills (i.e. the ability to navigate around the game space). Critical literacy in turn refers to the ability for a critical reflection of games, gameplay, and game culture. While functional literacy can be practised simply by playing different kinds of games, critical literacy requires different means. Mertala and Salomaa (2016) have suggested that game literacy education in ECE could mean, for example, asking children why they like certain games, and when playing games is fun and when it's not, by using visual or embodied mediums - drawing, crafting and acting - to support children's narration. One of the educational goals behind such practice is to help children to recognize how game mechanisms influence the range of emotions that they experience during and after the gameplay (e.g. frustration/ enjoyment after failing/succeeding at a challenge).

Buckingham (2015) also emphasizes that educators need to be aware of children's experiences of digital media. However, according to Aubrey \& Dahl (2014), such knowledge is rare among the ECE practitioners. Nonetheless, Finnish children's domestic media use has been studied regularly during the 2010s. According to the latest children's media barometer, almost every Finnish household with a 5-6 year-old has a television, computer, smartphone and internet connection. $99 \%$ of children were reported to watch movies or children's programs at least on a weekly basis, either as television broadcasts or on the internet. Pikku Kakkonen ${ }^{4}$ and Moomins were the most watched programs. $71 \%$ of children were reported to play digital games at least once a week. Angry Birds, games at Lego.com and Super Mario were the most often played games. Gaming was more popular among boys than girls, and with the exception of Angry Birds, boys' and girls' game preferences were different. Smartphones, mostly belonging to the parents, were used by children more frequently for gaming than for making or receiving calls. (Suoninen, 2014.)

However, it is important to understand that as the data wasn't collected from the children but from their guardians, these findings may disclose more about the guardians' media preferences than those of the children. In other words, these findings report on what children are allowed to do, not necessarily on what they would like to do. For example, while the non-commercial Pikku Kakkonen was the most watched TV show (Suoninen, 2014), children tend to

4. A daily children's TV-program aired by the Finnish National Broadcasting Company 
evaluate commercial TV-programs above the non-commercial ones (Ylönen, 2012). Use, knowledge and skills also shouldn't be understood as the same thing. Children with little access to technological devices can be very knowledgeable and up-to-date with respect to digital technologies, but not necessarily skillful in using them (Chaudron, 2015.) According to Aarsand (2010), such knowledge can be important capital as children are found to sort their peers into different categories on the basis of their awareness of digital media, for instance games. Furthermore, children's skills can be quite narrow. For example, many of the children in McKenney and Voogt (2010) reported that they can play digital games independently, but that they need help with starting the game. In other words, they had the necessary functional software literacy, but not the hardware literacy (see Buckingham \& Burn, 2007).

\section{METHOD}

\section{Participants and research context}

The primary data for this study was collected from the children ( $N=103$ [ 49 girls and 54 boys]) of five kindergarten-based preschool groups from a city in Northern Finland. Supplementary data was collected from their teachers. The groups were participating in a development project funded by the Finnish National Board of Education. The aim of the project was to explore the pedagogical possibilities of affordable digital media equipment that could later be implemented into other settings. The data collection took place in October 2013, during the orientation period when ideas for the types and uses of digital media were gathered from children, their families and preschool personnel, and before any new digital media devices were purchased. This approach served two purposes: First, the ideas and views of all the stakeholders were asked to be taken into consideration to avoid the possibility of a technical intervention wherein the developmental goals and the methods for reaching them would be defined by actors outside of the learning community (see Carr \& Kemmis, 1986). Second, the development project was understood as an important opportunity for performing research in the field of digital media integration in ECE, which, nationally, had been very little studied.

The existent digital media (reported by the teachers) of the participating groups supports the findings of Alasuutari et al. (2014), in that there wasn't much digital media for children to use. Groups 3 and 4 had interactive whiteboards (IWB), but as the installation process for group 4's IWB was incomplete at the time of the data collection, it had not yet been used. The teachers of group 3 reported that their IWB was occasionally used for drawing and playing learning games. Groups 1 and 5 had desktop computers for children, but neither of them was in use, due to technical troubles. All groups had a laptop and smartphone with an internet connection for the teachers' administrative tasks. Due to safety regulations, the children weren't allowed to use them. The basic information of the participating groups is presented in table 1. 
TABLE 1. GROUPS PARTICIPATING IN THE STUDY

\begin{tabular}{|l|l|l|}
\hline & Children & Type of equipment found in classrooms \\
\hline Group 1 & $\begin{array}{l}9 \text { boys / } \\
13 \text { girls }\end{array}$ & $\begin{array}{l}\text { One laptop and smartphone for staff; one desktop for children } \\
\text { (not in use); one digital camera and one CD player for staff and } \\
\text { children }\end{array}$ \\
\hline Group 2 & $\begin{array}{l}16 \text { boys / } \\
7 \text { girls }\end{array}$ & $\begin{array}{l}\text { One desktop, smartphone, document camera and canvas for staff; } \\
\text { two CD players for staff and children }\end{array}$ \\
\hline Group 3 & $\begin{array}{l}12 \text { boys / } \\
9 \text { girls }\end{array}$ & $\begin{array}{l}\text { One laptop, smartphone, projector and CD player for staff; inter- } \\
\text { active whiteboard for staff and children (not in use) }\end{array}$ \\
\hline Group 4 & $\begin{array}{l}12 \text { boys / } \\
13 \text { girls }\end{array}$ & $\begin{array}{l}\text { One laptop, smartphone document camera and projector for staff; } \\
\text { interactive whiteboard for staff and children }\end{array}$ \\
\hline Group 5 & $\begin{array}{l}5 \text { boys / } \\
7 \text { girls }\end{array}$ & $\begin{array}{l}\text { One desktop and smartphone for staff; one desktop for children } \\
\text { (not in use) }\end{array}$ \\
\hline
\end{tabular}

\section{Children's drawings as research data}

The research of children's drawing has a long tradition of analysis through graphic, perceptive and psychological lenses. However, lately, drawing has been recognized as a form of narration and knowledge construction. (Einarsdottir, Dockett \& Perry, 2009). From this perspective, drawing is understood to be an enjoyable form of action, which provides children with opportunities to think, remember, gain ideas, observe and record (Horn \& Giacobbe, 2007; Wright, 2010). This reflective interpretation of drawing suggests that children's drawings do not take shape in a "cultural vacuum" and, according to Anning and Ring (2004), children's drawings are always influenced by the communication and symbol systems around them. Children may, for example, include the characters of their favorite games and TV shows in the drawings they produce in preschool (Ylönen, 2012). Also, the context in which the drawings are made and the audience to whom they will be shown are meaningful for the children's drawing experience (Burkitt, Watling \& Murray, 2011; Einarsdottir et al., 2009). Drawings produced at an institutional education thus differ from the ones produced at home and drawings with instructions differ from children's spontaneous drawings. Drawing can also be intentionally combined with other forms of narration, as the use of visual method aids can help children express their ideas more easily (Spyrou, 2011). The strength of such an approach is that by using the drawing as a mediating tool, different parties are better able to understand each other's thinking by creating a transitional space in which their thoughts and ideas can be externalized into concrete form (e.g. Anning \& Ring, 2004; Horn \& Giacobbe, 2007).

\section{Data collection}

Diressnack (2006) has operationalized the aforementioned principles into a data collection method she has named "the draw and tell conversation method" (DTC). In DTC, children are first given a specific art directive that reflects the 
study purpose. When the drawing is ready, a conversation facilitated by an interview guide is carried out and recorded. This study has applied the aforementioned method with the exception that no recordings were made, but children's comments were written down on the drawings (see Einarsdottir et al., 2009). Drawings and interviews were introduced as a common preschool task and the data collection was conducted by the teachers, whilst I was absent. Drawing and interview situations were guided by a short manual that was sent to the teachers prior to the data collection. Informed consent was asked from the children and their guardians.

Before drawing, a short instruction was given to the children:

"First, write your name on the paper. Second, if there was digital media for example, computers, cameras, tablets or smartphones - at preschool, what should it be and what would you like to do with it? Draw your ideas on the paper. You can write as well if you want."

Instructions for the teachers for the drawing part were:

"If the children don't understand the terms used in the instruction, they should be opened in a way that doesn't contain examples of how the devices can be used. If there is a reluctance or resistance towards the task, you can encourage the children, but avoid strict guidance. Also, if the children want to create their own futuristic "supercomputers" etc. that's naturally appropriate."

After the drawing, one child at a time was interviewed by the teachers. For the interview, the instructions for the teachers were:

"Ask the children to name the devices they have drawn and how they are used in the picture. If there are human figures in the drawing, ask the children to name them and explain how they relate to them, if the person in question is not the child him/herself."

The example devices used in the instructions have decidedly influenced the children's drawings. This skewness in the data has been taken into account in the analysis and research questions. In other words, the present paper is not arguing to give insight on what devices children would like to have in preschool from a "tabula rasa" position. Instead, it pays attention to what kind of activities they would like to carry out with different kinds of devices. Also, the example devices weren't chosen at random, but they were based on the developmental aims of the project. As one of the key aspects of the project was to test the pedagogical possibilities of affordable digital media the most expensive classroom technologies, such as interactive whiteboards and interactive projectors, were excluded from the examples. 


\section{Analysis}

In his article on the practical and philosophical foundations of mixed methods research, Biesta $(2010,101)$ called the use of mixed methods a "combination of measurement and interpretation". Biesta's choice of words can be understood to refer either to data collection or to the analytic framework of the data. From the point of data collection, this combination means that the researcher collects two types of data: one that $\mathrm{s} / \mathrm{he}$ is going to measure (quantitative), and the other that $\mathrm{s} / \mathrm{he}$ is going to interpret (qualitative). From the point of view of an analytic framework, this combination means that the researcher can combine and mix different approaches and methods for a single type of data (see Johnson \& Onwuegbuzie, 2004). Onwuegbuzie, Slate, Leech and Collins (2007) have operationalized the second viewpoint into a method they call «monotype mixed analysis», which allows a single type of data, be it quantitative or qualitative, to be measured, as well as interpreted. The use of the method requires that qualitative data be altered into a form that can be analyzed statistically, and that quantitative data be transformed into data that can be analyzed qualitatively.

The data used in the present study, texts and drawings, are commonly described as qualitative (e.g. Biesta, 2010; Patton, 2002). In the context of the present paper, measurement refers to getting an overall picture of which activities and devices were the most frequently drawn and mentioned among the whole population of participants. Here transformation of the data meant quantifying the occurrence of how often different activities and devices were drawn and mentioned. Interpretation, in turn, refers not only to the examination of the holistic impression of the drawings by attempting to locate the cultural aspects reflected in them (see Anning \& Ring, 2004; Selwyn 2009a), but also to the intention to capture the diversity of the data by giving space for the ideas from individual children. Much of the former research on children's views and ideas considering the use of digital media in preschool has been done either as measurement (e.g. McKenney \& Voogt, 2010) or as interpretation (e.g. Aubrey \& Dahl, 2014; Morgan, 2010), not as a combination. Thus monotype mixed analysis wasn't chosen just because of the suitability (Biesta, 2010; Johnson \& Onwuegbuzie, 2004; Onwuegbuzie et al., 2007), but also as a means for providing a more comprehensive picture of the phenomenon under discussion.

Picture 1 is a representative example of the data. In it the child has sketched three different devices. Below them are written down the child's comments of what she would like to do with these devices ${ }^{5}$.

5. I have consulted another researcher to ensure that all the translations are as "true" to the original expressions as possible. 

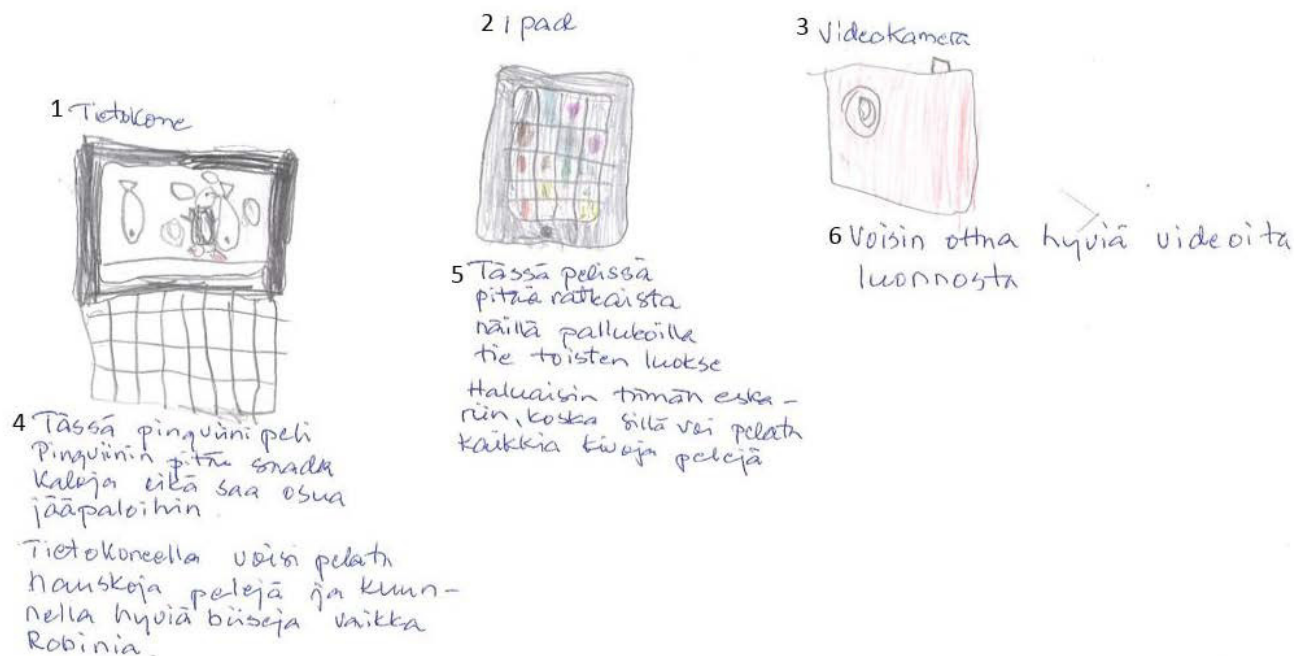

Picture 1. Example picture 1 (girl\#4).

FIGURE 1. TRANSLATED QUOTATIONS OF PICTURE 1

\begin{tabular}{|c|l|}
\hline No & Quotation \\
\hline 1 & Computer \\
\hline 2 & iPad \\
\hline 3 & Video camera \\
\hline 4 & $\begin{array}{l}\text { Here [is] a penguin game. The penguin must catch the fishes, but it should not touch the ice } \\
\text { bricks. With a computer, one could play fun games and listen to good songs, like Robin. }\end{array}$ \\
\hline 5 & $\begin{array}{l}\text { In this game, one must use these balls to find a route to the other ones. I'd like to } \\
\text { have this in preschool cause all the fun games can be played with it. }\end{array}$ \\
\hline 6 & \begin{tabular}{l} 
I could take good videos of nature \\
\hline
\end{tabular} \\
\hline
\end{tabular}

The data presented in Picture 1 was analyzed to include gaming with a computer and tablet (i.e. "I'd like to have this $\left[\mathrm{iPad}{ }^{\circledR}\right]$ in preschool cause all the fun games can be played with it"). In Finnish, unlike in English, there are distinct terms for playing a game (pelata), playing i.e. a role play, construction play, imaginary play (leikkiä), and playing an instrument (soittaa), which makes it easier to recognize which form of playing children are referring to, even if there are no clarifying terms like "game" used. Picture 1 was furthermore understood to include media production with a video camera ("I could take good videos of nature") and media reception with a computer" (one could--listen to good music, like Robin" [a Finnish singer]). This particular data was also understood to contain references to using digital media to have a good time in preschool (i.e. "---one could play fun games"). Moreover, naming the tablet as an $\mathrm{iPad} \AA$ was interpreted to reflect the prevailing media cultural sphere, as at the time of the study iPad ${ }^{\circledR}$ sales were breaking records in Finland ${ }^{6}$. More extracts from the data are presented in the Results section to improve the reliability and clarity of the research.

6. https://www.apple.com/fi/pr/library/2013/10/28Apple-Reports-Fourth-Quarter-

Results.html(retrieved 18.5.2016) 


\section{RESULTS}

The findings of this study are presented in two sections. The first one discusses the activities children expressed they would like to carry out in preschool. The second examines the cultural and contextual reflections expressed in the drawings and interviews. The distribution of different activities and devices are presented in Table 2. The left side of the table deals with the activities. For example, gaming was mentioned by 86 individual children, which consists of $83 \%$ of the participants. 38 of them were girls and 48 were boys, corresponding to $78 \%$ of the girls and $89 \%$ of the boys participating in the study. At the far right of the table the number of times different activities were mentioned in total are presented. In the case of gaming, the number was 119, which is higher than the amount of the children, as several children expressed that they would like to use several devices for playing games (see Picture 1). The presentation of devices follows the same logic: 73 children mentioned computers, which corresponds to $71 \%$ of the participants. 39 of them were girls and 34 boys, amounting to $80 \%$ of the girls and $63 \%$ of the boys. Besides the computers, the girls mentioned cameras and smartphones notably more often than the boys. Likewise, the boys mentioned tablets notably more often than the girls.

TABLE 2. ACTIVITIES AND DEVICES

\begin{tabular}{|c|c|c|c|c|c|c|c|c|c|c|c|c|c|c|}
\hline & & & \multirow{3}{*}{ All } & \multirow{2}{*}{\multicolumn{2}{|c|}{\begin{tabular}{|l} 
Computer \\
$73 / 71 \%$ \\
\end{tabular}}} & \multirow{2}{*}{\multicolumn{2}{|c|}{$\begin{array}{c}\text { Tablet } \\
50 / 49 \%\end{array}$}} & \multirow{2}{*}{\multicolumn{2}{|c|}{$\begin{array}{l}\text { Camera } \\
48 / 47 \%\end{array}$}} & \multirow{2}{*}{\multicolumn{2}{|c|}{$\begin{array}{c}\begin{array}{c}\text { Smart- } \\
\text { phone }\end{array} \\
17 / 17 \%\end{array}$}} & \multirow{2}{*}{\multicolumn{2}{|c|}{$\begin{array}{l}\text { Television } \\
12 / 12 \%\end{array}$}} & \\
\hline & & & & & & & & & & & & & & \\
\hline & & & & $\begin{array}{c}39 \\
80 \%\end{array}$ & $\begin{array}{c}34 \\
63 \%\end{array}$ & $\begin{array}{c}18 \\
37 \%\end{array}$ & $\begin{array}{c}32 \\
59 \%\end{array}$ & $\begin{array}{c}29 \\
59 \%\end{array}$ & $\begin{array}{c}19 \\
35 \%\end{array}$ & $\begin{array}{c}14 \\
29 \%\end{array}$ & $\begin{array}{c}3 \\
6 \%\end{array}$ & $\begin{array}{c}5 \\
10 \%\end{array}$ & $\begin{array}{c}7 \\
13 \%\end{array}$ & \\
\hline & All & Girls & Boys & Girls & Boys & Girls & Boys & Girls & Boys & Girls & Boys & Girls & Boys & Total \\
\hline Gaming & $\begin{array}{c}86 \\
83 \%\end{array}$ & $\begin{array}{c}38 \\
78 \%\end{array}$ & $\begin{array}{c}48 \\
89 \%\end{array}$ & 34 & 34 & 11 & 29 & - & - & 6 & 1 & $2^{\mathrm{a}}$ & 2 & 119 \\
\hline Media production & $\begin{array}{c}49 \\
48 \%\end{array}$ & $\begin{array}{c}25 \\
51 \%\end{array}$ & $\begin{array}{c}24 \\
44 \%\end{array}$ & 8 & 6 & 2 & 2 & 24 & 18 & 4 & 1 & - & - & 65 \\
\hline Media reception & $\begin{array}{c}36 \\
35 \%\end{array}$ & $\begin{array}{c}18 \\
37 \%\end{array}$ & $\begin{array}{c}18 \\
33 \%\end{array}$ & 13 & 6 & 3 & 4 & 1 & 3 & 3 & - & 3 & 5 & 41 \\
\hline Interaction & $\begin{array}{c}17 \\
17 \%\end{array}$ & $\begin{array}{c}11 \\
22 \%\end{array}$ & $\begin{array}{c}6 \\
11 \%\end{array}$ & 5 & 2 & - & - & 5 & 2 & 3 & - & - & - & 17 \\
\hline Learning & $\begin{array}{c}4 \\
4 \%\end{array}$ & $\begin{array}{c}4 \\
8 \%\end{array}$ & - & 3 & - & 1 & - & - & - & - & - & - & - & 4 \\
\hline Playing & $\begin{array}{c}3 \\
3 \%\end{array}$ & $\begin{array}{c}2 \\
4 \%\end{array}$ & $\begin{array}{c}1 \\
2 \%\end{array}$ & - & - & - & - & - & $1^{\mathrm{b}}$ & - & - & - & - & 3 \\
\hline
\end{tabular}

a. In three cases, gaming with a television means using a game console that is attached to the television. One child stated that she would like to play games with a TV without reference to any device being connected to it.

b. Two more children (a girl and a boy) said they would like to play [leikkiä] with walkie-talkies, which are not included in Table 2 . 


\section{Activities}

All the different activity categories (gaming, media production, media reception, interaction, learning, and playing) will be discussed in separate subsections. However, in terms of conclusive remarks it must be said that, similarly to Selwyn et al. (2009a), the children in this study used terms such as "fun" and "nice" regularly and regardless of the form of the activity. In addition, 21 times out of 24, the human figures using the digital media were represented as smiling (see Picture 3 later in the paper). To sum up, it is justified to say that the children, in general, had a positive attitude towards having digital media in preschool.

\section{Gaming}

"A tablet and computer could be used for playing games" (boy\#19)

"It'd be fun to play with a computer" (girl\#18)

35 of the 86 individual children who mentioned digital games referred only to gaming. 24 of them were boys, corresponding to $44 \%$ of boys showing interest only towards games. Comments such as "I just want to play games" (boy\#82) and "I like playing games a lot" (girl\#7) demonstrates well the piquancy of gaming. In 34 cases, the games were explicitly recognizable existing commercial entertainment games (e.g. Angry Birds, Super Mario, Pou). Tablets were understood almost solely as gaming devices. Smartphones were also connected more often to gaming than to interaction (i.e. making or receiving calls), and one of the children actually drew a smartphone, which she named a "gamephone" (girl\#64).

\section{Media production and media reception}

"It'd be fun to take pictures of animals with a camera" (boy\#65)

"One can write and draw with a computer" (girl\#88)

"I'd like us to watch movies from TV in preschool" (girl\#21)

Media production (mentioned by 49 children) consists of activities in which children produce different kinds of content with digital media. Taking photos and videos were the dominant activities in this category, followed by writing and drawing. Examples of the receiving of different content were conceptualized as media reception (mentioned by 36 children). It included watching movies and children's programs, listening to music and browsing photos without reference to taking photos. Friends, nature and animals were the most common targets that children wanted to take pictures and videos of (i.e. "I'd use a camera for taking pictures of nature, reptiles and my friends" [girl\#2]). Some of the children furthermore commented that they would like to take pictures and videos to document their doings in the preschool: 
"With this [camera], we could take pictures of the things we have done here" (boy\#49)

"With the camera, I'd take a picture of my drawing and a video of my playing" (girl\#86).

Significantly, even though tablets and smartphones can be used for taking photos and videos, a majority of the children named a camera as the tool for such an activity. Also, eight of the nine comments of taking pictures outdoors were explicitly linked to cameras. By excluding cameras from the analysis, the number of references to media production descends from 65 to 23 .

\section{Interaction}

"I'd like to show the pictures [I take] to others" (girl\#3)

"I could call my mommy and daddy" (girl\#74)

"I'm taking pictures of Lisa ${ }^{7}$. I put them on the computer and send them to Lisa's and my home" (girl\#13)

Interaction (mentioned by 17 children) was understood to take place when two or more actors shared the activity, either around digital media (as in the quote from girl\#3) or via digital media (as in the quote from girl\#74). As the third extract shows, sometimes these two forms were combined. Interaction partly overlaps with other categories. For example, the first quote is understood to be both - media production (photography) and interaction. Taking pictures or videos with and of friends, and watching them together was the most common form of interaction around digital media. Playing games was expressed as an interactional activity by only one child.

\section{Learning and playing}

"It'd be fun to practice reading with a computer" (girl\#69)

Learning (mentioned by 4 children) refers to activities in which children expressed a gain of knowledge or skills while using digital media. Besides the quoted girl, two other girls told that they would like to do calculations with a computer, and one commented that she would like to find information on train timetables and ticket prices. No children drew or mentioned teachers. This finding, combined with the high amount of references for playing commercial games, and watching movies and children's programs, implies that the use of digital media in preschool was mainly understood to be a leisure activity. For example, the drawing by one of the boys included the boy himself playing with a computer and his friends playing with toy caterpillars on the floor. In the interview, he said that "It was fun to play with the computer at preschool. The

7. Lisa is a pseudonym used to protect the identity of the participant 
others can play"8. This is understood to refer to the use of the computer taking place during free play time. Furthermore, two children said they would like to play with walkie-talkies in the preschool, the other also naming the camera as a device to play with.

1 "ESKARISSA OLI MUKAVA PENATA TIETOKONETTA. MUUT VOI LEIKKIĂ."

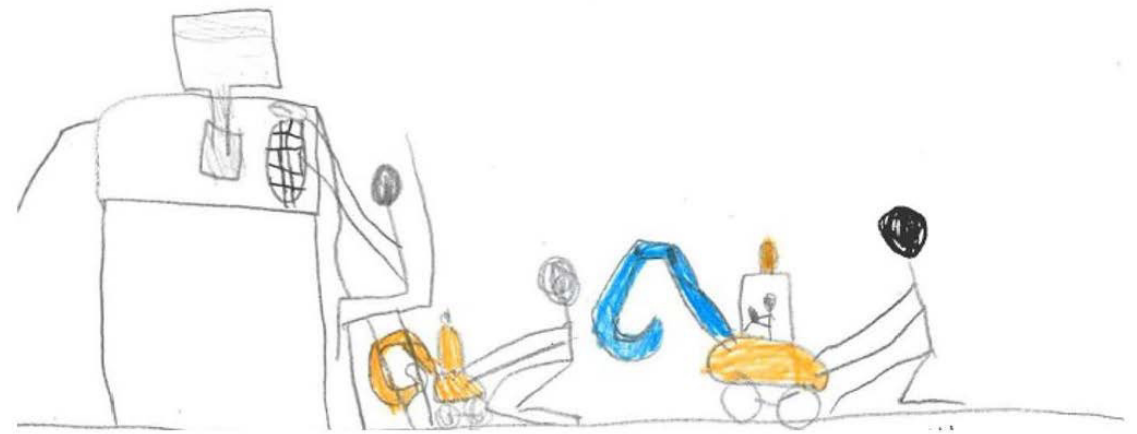

Picture 2. Example picture 2 (boy\#17)

FIGURE 2. TRANSLATED QUOTATIONS OF PICTURE 2

\begin{tabular}{|c|l|}
\hline No & Quotation \\
\hline 1 & It was fun to play with the computer at preschool. The others can play \\
\hline
\end{tabular}

\section{Cultural and contextual reflections}

Children's drawings don't take place in a cultural "vacuum" and the context in which the drawings are made and the instructions children are given have an impact on what they will draw (see Burkitt et al., 2011; Einarsdottir et al, 2009). Thus, not surprisingly, the most often drawn and mentioned devices were the ones used as prompts in the directive: computer (found in 73 drawings), tablet (50), camera (48) and smartphone (17) (see Table 2). One boy also drew the electric login card that is used when children enter the preschool. No IWBs were found in drawings, even though they were present in groups 3 and 4 (see Table 1). One explanation is that the children in groups 3 and 4 saw no reason to draw IWBs, as they already had them. It is also possible that the children in groups 1, 2 and 5 may not have been aware of the existence of IWBs, as they are a form of educational technology that is rare in Finnish ECE settings (see Alasuutari et al., 2014).

In the study by Selwyn et al. (2009a), children "imported" domestic devices and activities in their drawings. In the present paper, television (found in 12 drawings) was the most referred to form of digital media outside the instruction. This is best explained with their prevalence in Finnish households (Suoninen, 2014). Similarly, the activities reflected the findings of children's domestic media use. For example, children are reported using smartphones

8. Even though the boy used the past tense ("was"), there were no computers for children to use in his group 
more for gaming than for communicational purposes in their homes (Chaudron, 2015; Suoninen, 2014) and a similar phenomenon was apparent in the data of this study: playing games with smartphones was mentioned seven times and interaction (i.e. making calls) three times. Some of the children in this study also included detailed descriptions of how digital media is used by their families in their drawings. For instance, in the drawing by one of the boys (Picture 3 ), the ideas for digital media use in preschool ("One could play with tablet and computer") alternated with descriptions of how digital media is used in his family ("Daddy can pay the bills with the computer"). The strong reliance on domestic experiences can be understood to reflect the fact that due to the lack of equipment, there was hardly any existing culture of digital media use for children to reflect upon in their drawings.

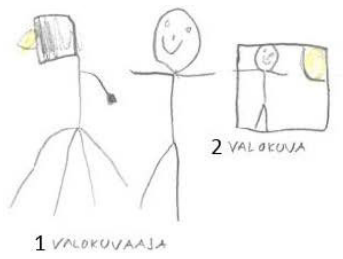

1 VALOKUVAAJA

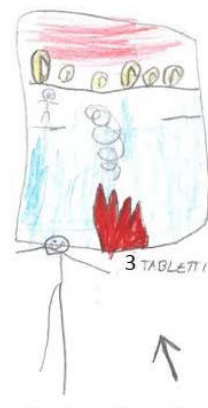

The boy himself (name removed)

"TABLETILLA JA TIETOKONEELLA

VOIS PELATA. TIETOKONEELLA IS:

VO) LASKET MAKSAA.

VUI PELATA MARIOA.

KAMERALCA VOI OTINA WALOKOUIA
UA VIOEOITA."

9 TELKKARISTA VOSI KATSOA MUTANTIKLPIKONNIA.

SATTEITA NETISSÄ.

Picture 3: Example picture 3 (boy\#23)

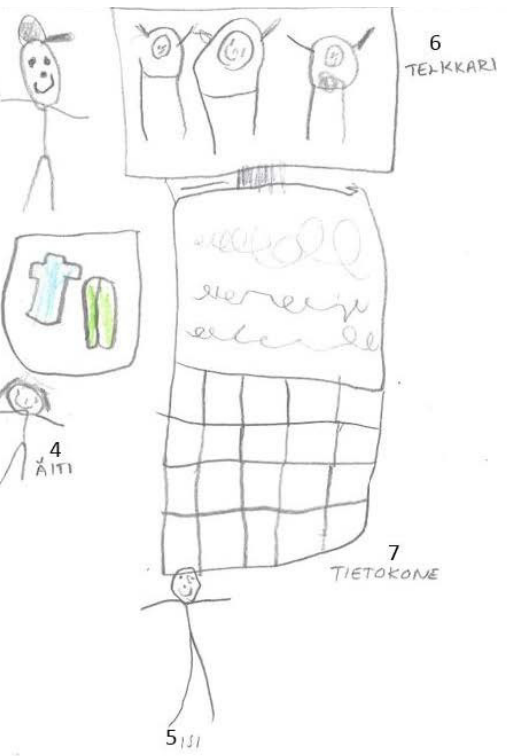

FIGURE 3. TRANSLATED QUOTATIONS OF PICTURE 3

\begin{tabular}{|c|l|}
\hline No & Quotation \\
\hline 1 & Photographer \\
\hline 2 & A photograph \\
\hline 3 & Tablet \\
\hline 4 & Mother \\
\hline 5 & Daddy \\
\hline 6 & Telly \\
\hline 7 & Computer \\
\hline 8 & One could play with a tablet and computer. Daddy can pay the bills with the com- \\
\hline 9 & puter. One can play Mario. One can take photographs and videos with the camera \\
\hline & \\
\hline
\end{tabular}


Some of the children represented notable knowledge of how certain devices look and how they function. For example, one of the boys drew a detailed picture of a tablet computer which, based on the shape of the home and back buttons in the left bottom corner, is apparently an Android tablet with a Jelly Bean operating system (Picture 4; see Appendix 1 for a reference picture). He also expressed knowledge of the functions of the hardware ("here's where the sounds are put on") and the software ("goes to a store where new games can be bought"). Conversely, one girl understood a tablet being a pill and drew a container full of tablets (Picture 5). This misconception could be caused by the practice that in Finnish early childhood classes, children are given xylitol tablets after lunch. Even though both of the examples are anecdotal by nature, they are still good reminders of the importance of not of thinking of children as a homogenous group with regard to their knowledge and experience of digital media (see Chaudron, 2015).

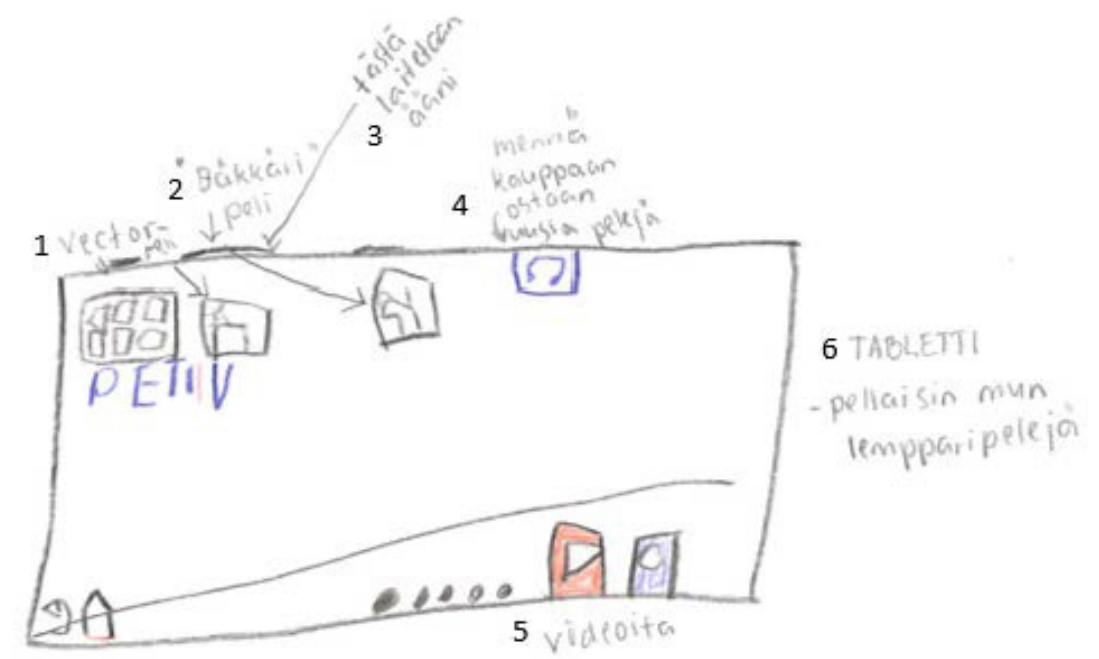

Picture 4. Example picture 4 (boy\#37)

FIGURE 4. TRANSLATED QUOTATIONS OF PICTURE 4

\begin{tabular}{|c|l|}
\hline No & Quotation \\
\hline 1 & Vector game \\
\hline 2 & "Backflip" game \\
\hline 3 & Here's where the sounds are put on \\
\hline 4 & Goes to a store where new games can be bought \\
\hline 5 & Videos \\
\hline 6 & Tablet. I'd play my favorite games \\
\hline
\end{tabular}




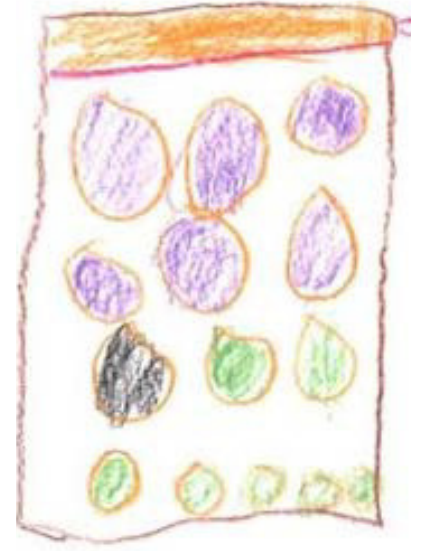

1 Tablettipurlei

Picture 5: Example picture 5 (detail) (girl\#68)
FIGURE 5. TRANSLATED QUOTATIONS OF PICTURE 5

\begin{tabular}{|c|l|}
\hline No & Quotation \\
\hline 1 & Tablet container \\
\hline
\end{tabular}

Tablets were also the only device that was connected to a certain brand. In 13 cases, a tablet was said to be an $\mathrm{iPad} \AA$, it being the most often mentioned brand in this study. The definition of a brand is loosely understood here as a trademark or a name of a product, or a content with no requirement to be especially well or widely known. With eight appearances, the second most mentioned was Angry Birds, which was the most played game by Finnish children of this age at the time of the data collection (Suoninen, 2014). Neppajymykerho was the only non-commercial reference, which supports the previous findings of children being often most interested in commercial media (Ylönen, 2012). Overall, different brands were found in 38 drawings ( 11 girls [22\%] \& 27 boys $[50 \%])$. The variety of different brand references is presented in Figure 6.

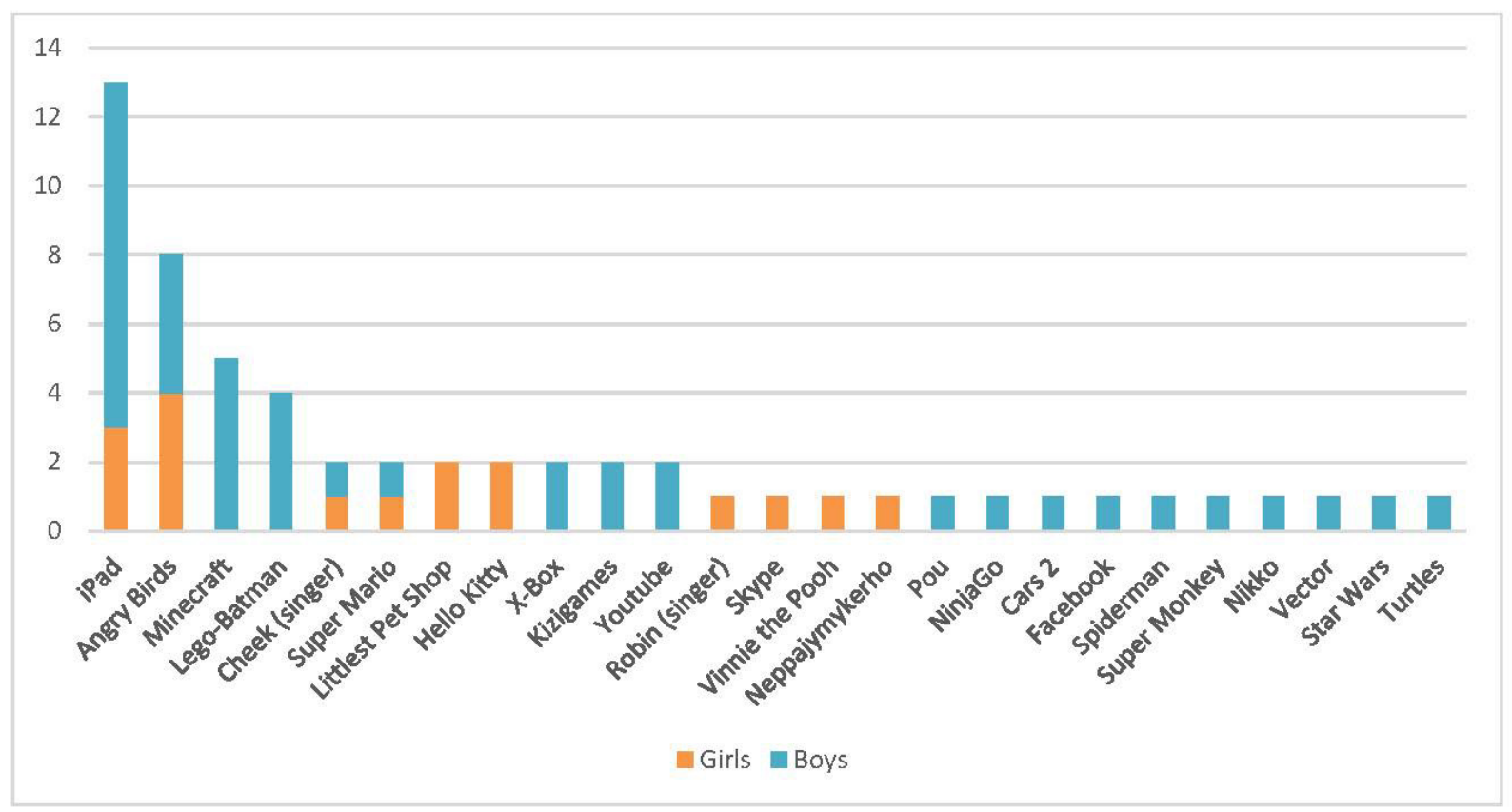

Figure 6. Brands expressed in drawings

In addition to recognizable brands, there were a notable amount of references to "monster games" (boy\#11, boy\#99), "racing/car games" (boy\#22, boy\#30; girl\#66) and "princess games (girl\#34, girl\#59) that are most likely commercial games, but weren't possible to link unambiguously to any specific product. For example, the steep uphill in the car game represented in the Picture 6 implies it to be a mobile game called Hill Climb Racing (see Appendix 2 for a reference picture). With these indicative references included, brands were found from a total of 67 drawings ( 25 girls [51\%] \& 42 boys [78\%]). 


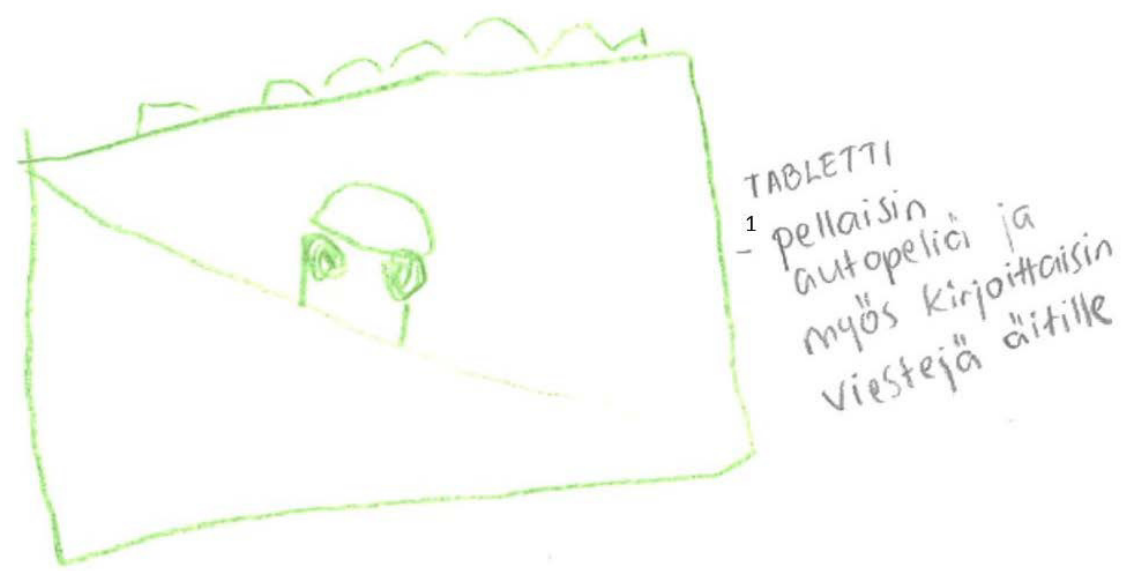

Picture 6. Example picture 6 (detail) (boy\#55)

FIGURE 7. TRANSLATED QUOTATIONS OF PICTURE 6

\begin{tabular}{|c|l|}
\hline No & Quotation \\
\hline 1 & Tablet. I'd play a car game and also write messages to my mother \\
\hline
\end{tabular}

\section{DISCUSSION}

The present study has given Finnish children a forum to express their ideas and wishes for the use of digital media in preschool. By doing so, this research has provided useful information for educators, policymakers and academics to take into consideration when planning ECE policies, pedagogical activities or research designs. In saying this, I am not claiming the findings to be exhaustive or generalizable. One reason for this is the geographically homogenous nature of the data. Nonetheless, studies where children act as meaning makers are needed to gain a better understanding of their relationship with digital media. Besides its scientific importance, this sort of information, collected from their own classes, is highly valuable for early childhood educators: it is needed to carry out pedagogy that is built on the strengths, needs, experiences and ideas of the children they educate (see Buckingham, 2015; FNBoE, 2014).

$83 \%$ of the children expressed a desire to play digital games in preschool, and $44 \%$ of the boys were interested only in gaming. The games the children referred to were mainly commercial entertainment games. As digital games have become a meaningful and regular part of the lives of young children in contemporary western societies (e.g. Aarsand, 2010; Chaudron, 2015), this is by no means a surprising finding. In my interpretation, this outcome should be considered in pedagogical planning in two ways.

First, digital games should be understood not only as a medium for learning, but also as a subject of learning (see Buckingham, 2015; FNBoE, 2014). According to Buckingham and Burn (2007), making games with children is an efficient method for practicing critical game literacy. Indeed, the rapid evolve- 
ment of easy-to-use game programming tools (e.g. Scratch) has lowered the competence needed to create simple digital games. However, more important than the form of the actual production is the knowledge construction that takes place during the pedagogical process, and the examination of digital games (as a cultural form) doesn't necessary require any digital instruments. Teachers might ask children to tell them about their favorite games through visual methods, such as drawing, to support their thinking and narration. This approach first positions children as experts and their teachers - who have been found to be unfamiliar with the contemporary digital media culture of children (Aubrey \& Dahl, 2014) - can learn a great deal from them. But, at the same time, teachers can guide the children's attention towards the things they are not yet aware of. This can be done with simple concrete questions like "why do you like this game", "do you know how this game was made?" In this way, children's favorite content, devices and activities can act as a starting point for phenomenon- and inquiry-based learning processes that go beyond merely using different digital devices and content with the children.

Second, it is important to provide children with meaningful and inspirational experiences of digital media, other than playing games. Media production, mostly taking pictures and videos, was the second most often referred activity by the children in this study. Also, early childhood educators have reported digital cameras as being motivational and easy to use tools for children. According to them, watching photographs with the children has broadened educators' views and understanding of what is meaningful for the children. (Mertala \& Salomaa, 2016.) In short, photographs and videos have the potential to become an effective tool for self-expression, communication, documentation and evaluation in early childhood education, and, thus, give children opportunities to act not only as takers, but also as makers of (digital) information. This is also one way in which to diversify the use of tablet computers, which are now mostly used for playing games in preschool (Blackwell et al., 2016) as well as at home (Chaudron, 2015).

While the last two chapters have been about the most mentioned activities, gaming and media production, I am not by any means suggesting that these are the only themes and phenomena that early childhood educators should focus on. As is written in the Finnish core curriculum, "each child has the right to be heard, seen, noticed and understood as an individual and as a member of his or her community" (FNBoE, 2014). This also means that views and ideas that differ from the general line need to be taken into consideration and recognized in pedagogical planning. One girl in this study expressed that she would like to use the internet to study train timetables and ticket prices. In my view, such an idea is a fruitful and concrete starting point for examining different digital services and their role in our everyday actions. 


\section{ACKNOWLEDGEMENTS}

This work was funded by Jenny and Antti Wihuri Foundation. I would like to thank the anonymous reviewers of Nordic Journal of Digital Literacy for their valuable comments.

\section{APPENDIX}

Appendix 1

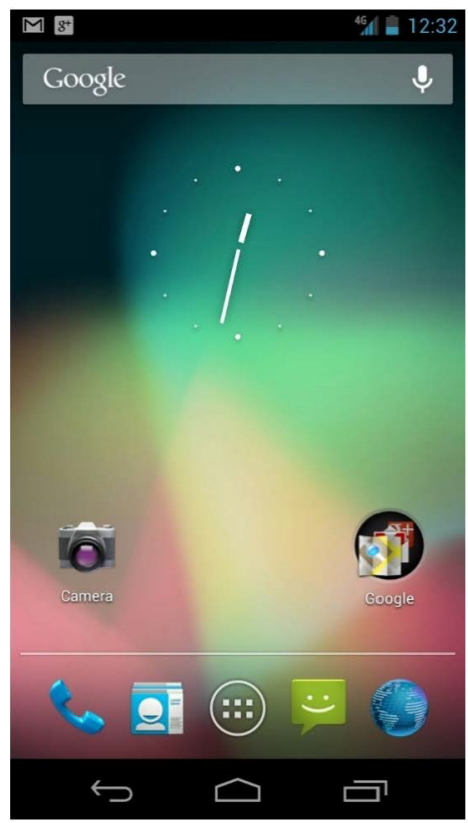

Picture 7. Android Jelly Bean OS 9

Appendix 2

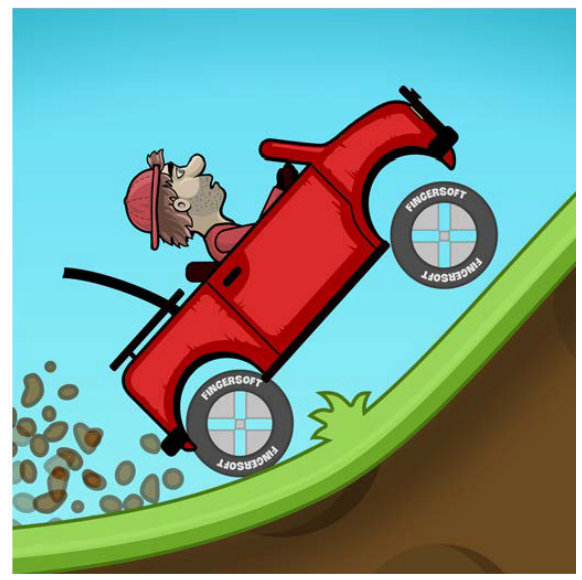

Picture 8. Hill Climb Racing ${ }^{10}$

9. By Android Open Source project, CC BY 2.5, https://commons.wikimedia.org/w/ index.php?curid=20262781 (retrieved 19.5.2016)

10. http://www.amazon.com/Fingersoft-Hill-Climb-Racing/dp/B00CSR2J9I (retrieved 24.5.2016) 


\section{REFERENCES}

Aarsand, P. (2010). Young Boys Playing Digital Games. Nordic Journal of Digital Literacy, 5 (1), 38-54.

Alasuutari, M., Karila, K., Alila, K. \& Eskelinen, M. 2014. Vaikuta varhaiskasvatukseen. Lasten ja vanhempien kuuleminen osana varhaiskasvatuksen lainsäädäntöprosessia. Opetus- ja kulttuuriministeriön työryhmämuistioita ja selvityksiä 2014:13. Retrieved from: http://www.minedu.fi/export/sites/default/OPM/Julkaisut/2014/liitteet/ tr13.pdf?lang=fi

Anning, A. \& Ring, K. (2004). Making sense of children's drawings. Maidenhead: Open University Press.

Aubrey, C. \& Dahl, S. (2014). The confidence and competence in information and communication technologies of practitioners, parents and young children in the early years foundation stage. Early Years: Journal of International Research \& Development, 34(1), 94-108. http://dx.doi.org/10.1080/09575146.2013.792789.

Biesta, G. (2010). Pragmatism and the philosophical foundations of mixed methods research. In A. Tashakkori \& C. Teddlie (Eds.), Sage Handbook Of Mixed Methods In Social And Behavioral Research. (2nd ed.). California, USA: Sage Publications, 95117.

Blackwell, C. K., Lauricella, A. R. \& Wartella, E. (2016). The influence of TPACK contextual factors on early childhood educators' tablet computer use. Computers \& Education, 98, 57-69.http://dx.doi.org/10.1016/j.compedu.2016.02.010.

Buckingham, D. (2015). Defining digital literacy-What do young people need to know about digital media? Nordic Journal of Digital Literacy, 9 (Special Issue), 21-35.

Buckingham, D. \& Burn, A. (2007). Game literacy in theory and practice. Journal of Educational Multimedia and Hypermedia, 16(3), 323-349.

Burkitt, E., Watling, D. \& Murray, L. (2011). Children's drawings of significant figures for a peer or an adult audience. Infant \& Child Development, 20(6), 466-473. http://dx.doi.org/10.1002/icd.735.

Carr, W. \& Kemmis, S. (1986). Becoming Critical: Education Knowledge and Action Research. Deakin University Press.

Chaudron, S. (2015). Young Children (0-8) and Digital Technology. A qualitative exploratory study across seven countries. Joint Research Centre. Luxembourg: Publications Office of the European Union.

Corsaro, W.A. (2005). The Sociology of Childhood. (2nd ed.). Thousand Oaks, Ca: Sage.

Driessnack, M. (2006). Draw-and-tell conversations with children about fear. Qualitative Health Research, 16(10), 1414-1435. http://dx.doi.org/10.1177/1049732306294127.

Einarsdottir, J., Dockett, S. \& Perry, B. (2009). Making meaning: Children's perspectives expressed through drawings. Early Child Development and Care, 179(2), 217-232. http://dx.doi.org/10.1080/03004430802666999.

Finnish National Board of Education (2014). Esiopetuksen opetussuunnitelman perusteet 2014. Opetushallitus: Määräykset ja ohjeet 2014: 94. Retrieved from: http://www.oph.fi/download/ 163781_esiopetuksen_opetussuunnitelman_perusteet_2014.pdf

Horn, M. \& Giacobbe, M. E. (2007). Talking, drawing, writing: Lessons for our youngest writers. Portland, Me: Stenhouse Publishers.

Howard, J., Miles, G. E. \& Rees-Davies, L. (2012). Computer use within a play-based early years curriculum. International Journal of Early Years Education, 20(2), 175189.http://dx.doi.org/10.1080/09669760.2012.715241

Johnson, R. B. \& Onwuegbuzie, A. J. (2004). Mixed methods research: A research paradigm whose time has come. Educational researcher, 33(7), 14-26. http://dx.doi.org/10.3102/0013189x033007014 
Kerckaert, S., Vanderlinde, R. \& van Braak, J. (2015). The role of ICT in early childhood education: Scale development and research on ICT use and influencing factors. European Early Childhood Education Research Journal, 23(2), 183-199. http://dx.doi.org/10.1080/1350293x.2015.1016804.

McKenney, S. \& Voogt, J. (2010). Technology and young children: How 4-7 year olds perceive their own use of computers. Computers in Human Behavior, 26(4), 656-664. http://dx.doi.org/10.1016/j.chb.2010.01.002.

Mertala, P. \& Salomaa, S. (2016). Kasvatuskeskeinen näkökulma varhaisvuosien mediakasvatukseen. In: L. Pekkala, S. Salomaa \& S. Spišák (Eds.) Monimuotoinen mediakasvatus. Kansallisen audiovisuaalisen instituutin julkaisuja 1/2016, 154-155. Retrieved from: http://www.mediataitokoulu.fi/monimuotoinen_mediakasvatus.pdf

Morgan, A. (2010). Interactive whiteboards, interactivity and play in the classroom with children aged three to seven years. European Early Childhood Education Research Journal, 18(1), 93-104. http://dx.doi.org/10.1080/13502930903520082.

Onwuegbuzie, A. J., Slate, J. R., Leech, N. L. \& Collins, K. M. (2007). Conducting mixed analyses: A general typology. International Journal of Multiple Research Approaches, 1(1), 4-17.http://dx.doi.org/10.5172/mra.455.1.1.4

Patton, M. Q. (2002). Qualitative Research and Evaluation Methods (3rd ed.). London: Sage

Plowman, L. (2016). Learning Technology at Home and Preschool. In: N. Rushby \& D.WSurry (eds.). The Wiley Handbook of Learning Technology. Chichester, UK: Wiley Blackwell, 96-112. http://dx.doi.org/10.1002/9781118736494.ch6.

Selwyn, N., Boraschi, D. \& Ozkula, S. M. (2009a). Drawing digital pictures: An investigation of primary pupils' representations of ICT and schools. British Educational Research Journal, 35(6), 909-928. http://dx.doi.org/10.1080/ 01411920902834282.

Selwyn, N., Potter, J. \& Cranmer, S. (2009b). Primary pupils' use of information and communication technologies at school and home. British Journal of Educational Technology, 40(5), 919-932. http://dx.doi.org/10.1111/j.1467-8535.2008.00876.x.

Spyrou, S. (2011). The limits of children's voices: From authenticity to critical, reflexive representation. Childhood, 18(2), 151-165. http://dx.doi.org/10.1177/ 0907568210387834.

Suoninen, A. (2014). Lasten mediabarometri 2014. 0-8-vuotiaiden mediankäyttö ja sen muutokset vuodesta 2010. Nuorisotutkimusverkosto / nuorisotutkimusseura julkaisuja 149. Helsinki, Unigrafia.

Wright, S. (2010). Understanding creativity in early childhood: Meaning-making and children's drawings. Los Angeles: SAGE.

Ylönen, S. (2012). Sallittua, salaista vai kiellettyä? Lasten medialeikkitilasta käydyt neuvottelut päiväkodissa. In: H. Strandell, L. Haikkola \& K. Kullman (Eds.) Lapsuuden muuttuvat tilat. Jyväskylä: Vastapaino, 85-115. 